\title{
Smart Indoor Air Quality Monitoring System
}

\author{
Supreet Kaur, Seemu Sharma, Seema Bawa
}

\begin{abstract}
Internet of Thing or IoT in its simplest form means “Connect the Unconnected". It makes our surroundings smarter and reactive as IoT enabled systems are capable of taking actions without human intervention. It has entered in almost all areas of life and has applications in various domains. Environment monitoring is one such domain. The air we breathe today is a mixture of harmful pollutants in high concentration. Not only outdoors, even indoors are not safe. This paper presents various IoT enabled Indoor Air Quality monitoring systems. It discusses what is indoor pollution, how it is degrading our health and how IoT is helping us to remain safe in indoors. It also stresses on the questions why indoor air pollution is to be addressed.
\end{abstract}

Keywords: Indoor Air Quality Monitoring System, Pollutant Classification, IoT, Wireless Sensor Network.

\section{INTRODUCTION}

Different authors, researchers, academicianshave defined IoT in many ways, however the core concept remains the same. IoT is, "An open and comprehensive network of intelligent objects that have the capacity to auto-organize, share information, data and resources, reacting and acting in face of situations and changes in the environment"[1]. IoT from its name clearly reveals that during Internet's first version people are source of data and in its second version things or objects arecreating data.It is impacting the computing and communication technology in future. The vision of IoT is to make objects smarter for better and easy world.

Internet is the core element of IoT which connects various heterogeneous devices [2].IoT has many applications in various domains. Smart Cities, Smart Homes, IoT in transportation, IoT in Industries, Public Safety etc. are few domains where IoT is working [3].Indoor Air Quality monitoring is an important application of IoT which is discussed in this paper.

The motivation behind this survey is the rising indoor air pollution and its harmful and deadly effects on humans. The indoors may include home, work-places, schools or other institution, industries. This article has discussed detrimental effects of air pollution on health. IoT can help in monitoring air pollution and in notifying users. The other factors of motivation are as follows:

Revised Manuscript Received on September 10, 2019.

Supreet Kaur, Department of Computer Science \& Engineering, Thapar Institute of Engineering \& Technology, Patiala, India.

Seemu Sharma, Department of Computer Science \& Engineering, Thapar Institute of Engineering \& Technology, Patiala, India.

Seema Bawa, Department of Computer Science \& Engineering, Thapar Institute of Engineering \& Technology, Patiala, India.

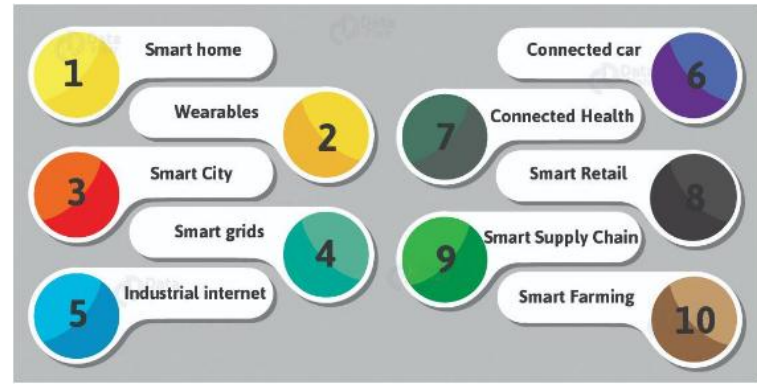

Fig.1. Applications of IoT [4]

A. Motivation for Carrying out the Analysis

- The need to discover presence of air pollution in our routine life (indoors and outdoors) both.

- The need to understand air pollution and its impact on human cognition.

- To understand existing IoT enabled indoor air monitoring applications.

Hence, the problem occurring by indoor air pollution needs to be addressed and solutions in the form of IoT technology should be determined.

\section{BACKGROUND}

Humans have come a long way and are growing from the ages, whether in terms of culture or the technology[5]. With the advancements in technology, the industries, weapons, environment surrounding us is deteriorating. Pollution is one such negative outcome of this revolution. Pollution is rising with the growing development. People are surrounded by number of objects which are causing pollution and affecting their health. With our modern lifestyle, where people tend to live more indoors are becoming victim of indoor air pollution. The present section comprises of in-depth study of pollution and its various types.It provides detail on indoor air pollution and how IoT is helping in monitoring and controlling pollution.

\section{A.Pollution}

Pollution is defined as "the contamination of the physical and biological components of the earth/atmosphere system to such an extent that normal environmental processes are adversely affected". Pollutants can be man-made or can occur naturally, but when certain level is exceeded, they pollute the environment [6].Pollution is said to be "greatest headache of mankind" [7] as it leads to millions of premature deaths of humans worldwide [8]. It is presently the major health hazard for humans and other life forms on earth. 
According to World Health Organization (WHO) "4.2 million death occur due to ambient air pollution and 3.8 million deaths to household pollution"[9].

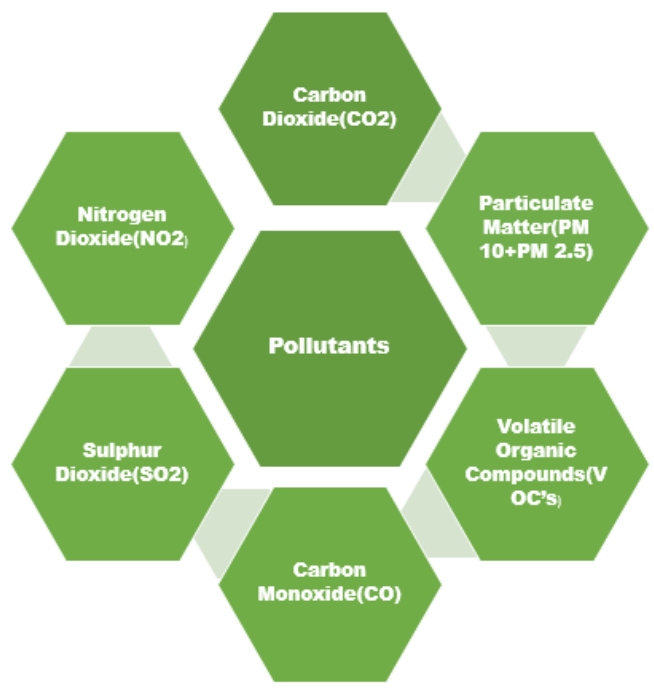

Fig. 2. Air Pollutants

There are many types of pollution, for e.g. air, water, land, noise, thermal etc.

Air Pollution: The environmental resource which is most polluted is air. Air pollution can be defined as "the introduction of harmful substances in the air that results in detrimental impacts to the environmental and humanity"[10]. It can occur naturally or can be man-made. Air pollutants which causes air pollution includes particulate matter (PM 2.5, PM 10), carbon monoxide (CO), volatile organic compounds (VOCs), carbon dioxide (CO2), nitrogen oxides $\left(\mathrm{NO}_{2}\right)$ and sulfur oxides $\left(\mathrm{SO}_{2}\right)$.

Water Pollution: It is "the act of contaminating water bodies namely rivers, oceans, lakes, streams, aquifers, and groundwater"[10]. It occurs when harmful materials like chemicals or waste matter, are released into water bodies either directly or indirectly. The water pollution is mainly caused by human activities as they introduce substances such as harmful chemicals and toxic materials which contaminate water. Oil spills, industrial wasted, pesticides used in agriculture, release of detergents and plastic in water are the major causes of water pollution.

Noise Pollution: It is an unwanted sound which causes discomfort to ears. It is measured in decibels (dB). Permanent hearing loss can be caused by sound levels beyond $100 \mathrm{~dB}$. "The industrial sound limit according to the World Health Organization (WHO) is 75 decibels"[10]. It affects humans as well as marine and wildlife animals. It may cause death of animals.Sound pollution is never accumulated like other types of pollution. It occurs for short period but can cause severe health effects.

Land Pollution: Land pollution can be defined as "the destruction or decline in quality of the earth's land surfaces in term of use, landscape and ability to support life forms" $[10]$. Most of the times, it is caused by human activities. Land pollution takes place when garbage is not disposed of in the right manner. Land pollution is mainly

caused by construction sites, solid waste, mineral exploitation, agricultural chemicals, and deforestations and acid rain.

Thermal Pollution:Thermal pollution is "the harmful release of heated liquid into a body of water or heat released into the air as a waste product of a business"[10]. With the sudden increase or decrease of temperature of natural bodies like rivers, ponds, lakes etc. thermal pollution occurs.

Radioactive Pollution: "Radioactive pollution is defined as increase in natural radiation levels caused by human activities"[11]. The most common sources of radioactive pollution include disposing nuclear waste improperly, use of nuclear weapons, accidents in nuclear power plants[12].

Light Pollution: "Light Pollution is an over illumination of an area that is considered obtrusive". The most common sources of light pollution include large metropolitan cities, advertisements and billboard, night events [11].Author (s) can send paper in the given email address of the journal. There are two email address. It is compulsory to send paper in both email address.

\section{B.Forecasting of Air Pollution}

Nowadays, forecasting of air pollution is done which is applicable to both indoor and outdoor environments. Here, Artificial Neural Network Model is used for forecasting air pollution. Actions can be taken beforehand to minimize loss [13],[14].

Air Pollution is present in both indoors and outdoors. Industries are the major source of pollution in outdoor environment [15].

\section{C.Indoor Air Pollution}

Air pollution is not limited to outdoor. Even indoor spaces are not free from it. Indoor air quality refers to the quality of air inside and around buildings. The major indoor air pollutants include Particulate Matters (PM 10, PM2.5), Carbon Dioxide $\left(\mathrm{CO}_{2}\right)$, Carbon Monoxide (CO) and Volatile Organic Compounds (VOCs). The more vulnerable age group to indoor air pollutants are children [16]. A study shows that pollution caused by biomass fuels effects children than other age group people [17].

As, we spend maximum time indoors in schools, offices, hospitals, recreation zones etc., our healthy is affected. Generally, people thinks indoors are less polluted than outdoors. But, according to a study indoor pollutants are two to four more than outdoors [18],[19].It is becoming an invisible killer to human health [20]. Thus, this issue of indoor air pollution needs to be addressed. For prevention and avoidance of air pollution, real time monitoring is essential. IoT can help in real time monitoring and sharing of collected data in real time using cloud[21].

Classification of indoor air pollutants and its sources is another aspect of this study. Major cause of indoor air pollution in educational institutions and in homes respectively has been discussed by many researchers. $[23,24]$. 
Furniture making, wall paint and occupants itself are the sources of pollution in educational institutes and in homes cleaning products, pest and insect repellents and odor neutralizers are the major causes of pollution. However, other sources of indoor air pollution can be classified as chemical presence, human and fragrance (as shown in Table 1).

TABLE I. CLASSIFICATION OF INDOOR AIR POLLUTANTS

\begin{tabular}{|c|c|c|c|}
\hline $\begin{array}{l}\text { Classification } \\
\text { of indoor air } \\
\text { pollutants }\end{array}$ & $\begin{array}{l}\text { Products } \\
\text { causing air } \\
\text { pollution }\end{array}$ & Home/Work & $\begin{array}{l}\text { Pollutants } \\
\text { present in air } \\
\text { pollution }\end{array}$ \\
\hline $\begin{array}{l}\text { Chemicals } \\
\text { Presence }\end{array}$ & $\begin{array}{l}\text { Floor } \\
\text { Cleaners, } \\
\text { Glass } \\
\text { Cleaners, } \\
\text { Insect } \\
\text { Repellent }\end{array}$ & $\begin{array}{l}\text { Home and } \\
\text { Work }\end{array}$ & VOC's \\
\hline Human Activity & $\begin{array}{l}\text { Cigarettes, } \\
\text { Cooking }\end{array}$ & $\begin{array}{l}\text { Home and } \\
\text { Work }\end{array}$ & $\begin{array}{l}\text { Carbon } \\
\text { Monoxide, } \\
\text { formaldehyde, } \\
\text { ammonia, } \\
\text { hydrogen } \\
\text { cyanide, } \\
\text { arsenic, vinyl } \\
\text { chloride; } \\
\text { Carbon } \\
\text { Monoxide, } \\
\text { nitrogen } \\
\text { dioxide, } \\
\text { formaldehyde, } \\
\text { carbon dioxide, } \\
\text { particulate } \\
\text { matter }\end{array}$ \\
\hline $\begin{array}{l}\text { Fragrance } \\
\text { Presence }\end{array}$ & $\begin{array}{l}\text { Incense } \\
\text { Sticks, } \\
\text { Room } \\
\text { Fresheners, } \\
\text { Perfumes }\end{array}$ & $\begin{array}{l}\text { Home and } \\
\text { Work }\end{array}$ & $\begin{array}{l}\text { VOC's, sulphur } \\
\text { dioxide, } \\
\text { formaldehyde, } \\
\text { carbon } \\
\text { monoxide, } \\
\text { particulate } \\
\text { matter, oxides } \\
\text { of nitrogen; } \\
\text { VOC's; VOC's, } \\
\text { carbon dioxide }\end{array}$ \\
\hline
\end{tabular}

\section{D.How Health is Impacted by Indoor Air Pollution?}

Nowadays, as most of the time is spent indoors [25] , there is need to focus on indoor air pollution. It exists within buildings such as schools, offices, homes, hospital etc. There are lot of health risks associated with it. The impact of pollutants depends upon their concentration, exposure time and vary from person-to person[26].

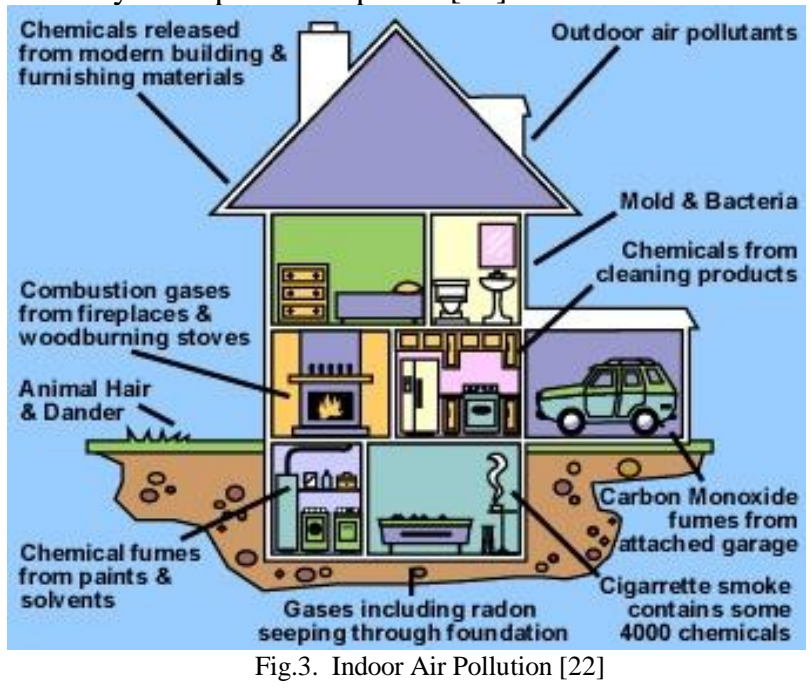

Air pollution can cause allergies, eyes/throat, skin irritations, dizziness, headaches, respiratory diseases such as asthma, cough and cardiovascular diseases [27,23]. Indoor Air Pollution is the $4^{\text {th }}$ top carcinogen according to a study conducted by U.S Environmental Protection Agency(EPA) in 1987 [23]. Also, EPA has ranked indoor air pollution as highest risk to human health, among all environmental problems [28]. Carbon Monoxide (CO) at very high concentration can cause death [11]. Poor Air can cause lung infections such as bronchial asthma or chronic obstructive pulmonary disease. Due to pollution children may develop diabetes or neurological disorders. It also adversely effects pregnant ladies[9]. According to a research, air pollution effects sperm quality in men[29]. It can also be responsible for dementia[30]. Cognition skills such as arithmetic and communication are also effected by air pollution[31].

\section{IOT AND INDOOR AIR POLLUTION}

As IoT has touched every aspect of our lives today,many scientist and researchers are working or have started working continuously in the area of air pollution. From simple applications to complex applications have been developed and integrations of applications is being made. IoT enabled air purifiers are being made which can be controlled by smartphones.

\section{A. Why choose IoT to address Indoor Air Pollution?}

IoT can be thought of as "global network which allows the communication between human-to-human, human-to-things and things- to- things, which is anything in the world by providing unique identity to each and every object"[32]. In the ICT sector development of emerging technologies is largely impacted by IoT [33].The architecture of IoT explains well the reason behind choosing IoT to address Indoor Air Pollution.

The most basic architecture of IoT is 3-layer model (as shown in Fig. 4). It includes:

- Perception Layer: This layer contains objects and sensors and is also termed as device layer.

This layer is responsible for collecting data and information. It encompasses of technologies like RFID tags, sensor networks, GPS and terminals. Wireless sensor networks are considered more accurate for monitoring and controlling of physical environments [34].

- Network Layer: This layer is used for transmission and processing of data received from perception layer. It encompasses technologies like Wi-Fi, Zigbee, Bluetooth etc. this layer acts as information center and network center.

- Application Layer: This layer focuses social 
division of IoT and industry requirements. Various virtual market comes under application layer.

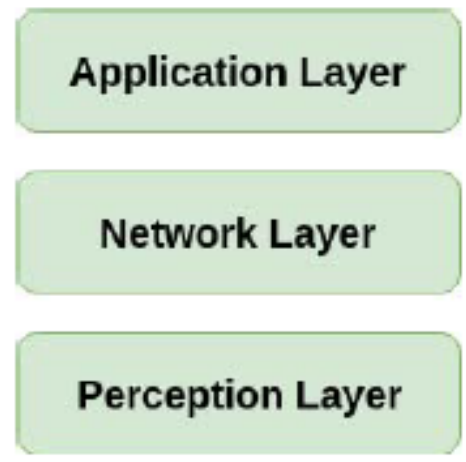

Fig. 4. Basic architecture of IoT[35]

\section{RESEARCH METHODOLOGY}

This section describes the research motive of the paper. It focuses on encouraging factors for carrying out the review and describes the methodology used for review in detail.

\section{A. Review Plan}

The review plan includes research question designing, followed by exploring various databases, further these databases are searched for particular topics or keywords. Resultant items have been analyzed. The research methodology for this article includes looking for research papers from databases such as IEEE Xplore, Elsevier, Springer, Science Direct, ACM Journal and Google Scholar. Then based on their relevancy, searched results have been organized.

\section{B. Research Questions}

The research questions along with their inspiring factors are presented in Table 2.

\section{Study Selection Procedure}

The first step involves identification of keywords for selecting research papers and other study materials. For proper research, internet or web is explored extensively. The topics researched includes Indoor Air Pollution using IoT, Pollution, Air Pollution, IoT, Classification of pollutants and wireless sensor networks for air pollution monitoring systems.

In the first phase of selecting research papers or study materials, there were 130 results which were simplified on the basis of research questions. In final count after thorough study and analyses, 53 research papers or other study materials were used in this article (as shown in Fig. 5).

TABLE II. RESEARCH QUESTIONS ALONG WITH THEIR MOTIVATION

\begin{tabular}{|l|l|}
\hline Research Questions & Motivation \\
\hline $\begin{array}{l}\text { How much important is to focus on } \\
\text { Indoor Air Pollution? }\end{array}$ & $\begin{array}{l}\text { With the current lifestyle, as we spend } \\
\text { more time indoors in schools/colleges, } \\
\text { offices, malls etc. and with } \\
\text { advancements in technology, indoor air }\end{array}$ \\
\hline
\end{tabular}

\begin{tabular}{|l|l|}
\hline & $\begin{array}{l}\text { pollution is increasing. Many people } \\
\text { around the globe know little about it as } \\
\text { compared to outdoor air pollution. }\end{array}$ \\
\hline $\begin{array}{l}\text { How harmful is indoor air } \\
\text { pollution? }\end{array}$ & $\begin{array}{l}\text { Indoor air pollution at moderate level } \\
\text { can cause dizziness headache, } \\
\text { tiredness, lack of concentration etc. At } \\
\text { higher rate it can lead to respiratory } \\
\text { issues, heart problems and impacts } \\
\text { human cognition. }\end{array}$ \\
\hline $\begin{array}{l}\text { Can technology play a role in } \\
\text { resolving the issue of indoor air } \\
\text { pollution? }\end{array}$ & $\begin{array}{l}\text { Yes, in technology sector, IoT can help } \\
\text { in monitoring or controlling indoor air } \\
\text { pollution through applications or } \\
\text { devices. }\end{array}$ \\
\hline $\begin{array}{l}\text { How much beneficial is IoT in case } \\
\text { of indoor air pollution? }\end{array}$ & $\begin{array}{l}\text { With the help of IoT, level of indoor air } \\
\text { pollutants can be measured and further } \\
\text { user can be notified. In an extensive } \\
\text { part, air purifier can also be integrated } \\
\text { with IoT applications. Thus, IoT is } \\
\text { extremely beneficial for indoor air } \\
\text { pollution. }\end{array}$ \\
\hline
\end{tabular}

\section{V.RESULTS AND DISCUSSIONS}

In this section, survey findings are discussed. "IoT can be thought of as global network which allows the communication between human-to-human, human-to-things and things- to- things, which is anything in the world by providing unique identity to each and every object"[32].

Following are the different proposed Indoor Air Quality Monitoring Applications based on pollutants measured, sensors used, classification of pollutants and adverse health impacts of pollutants.

A.IAQ Monitoring Applications for measuring CO2 using WSN's

The negative effect of carbon dioxide $(\mathrm{CO} 2)$ in indoor spaces has been presented in [36]. Even the slightest amount of $\mathrm{CO} 2$ impairs cognition of students in schools. The use of wireless sensors for measuring $\mathrm{CO} 2$ has been proposed in this research. Data is sent to server through wireless access points. The server side contains an application which alerts user when certain level of $\mathrm{CO} 2$ is reached. There are many other monitoring systems proposed by different authors for measuring $\mathrm{CO} 2$. In another study [21] for monitoring $\mathrm{CO} 2$ in real time, cognitive wireless sensor network systems are used. This technique leads to minimum interference with other systems which are already present.In another study [37]CO2is measured and further rate of ventilation is analyzed. 


\section{Smart Indoor Air Quality Monitoring System}

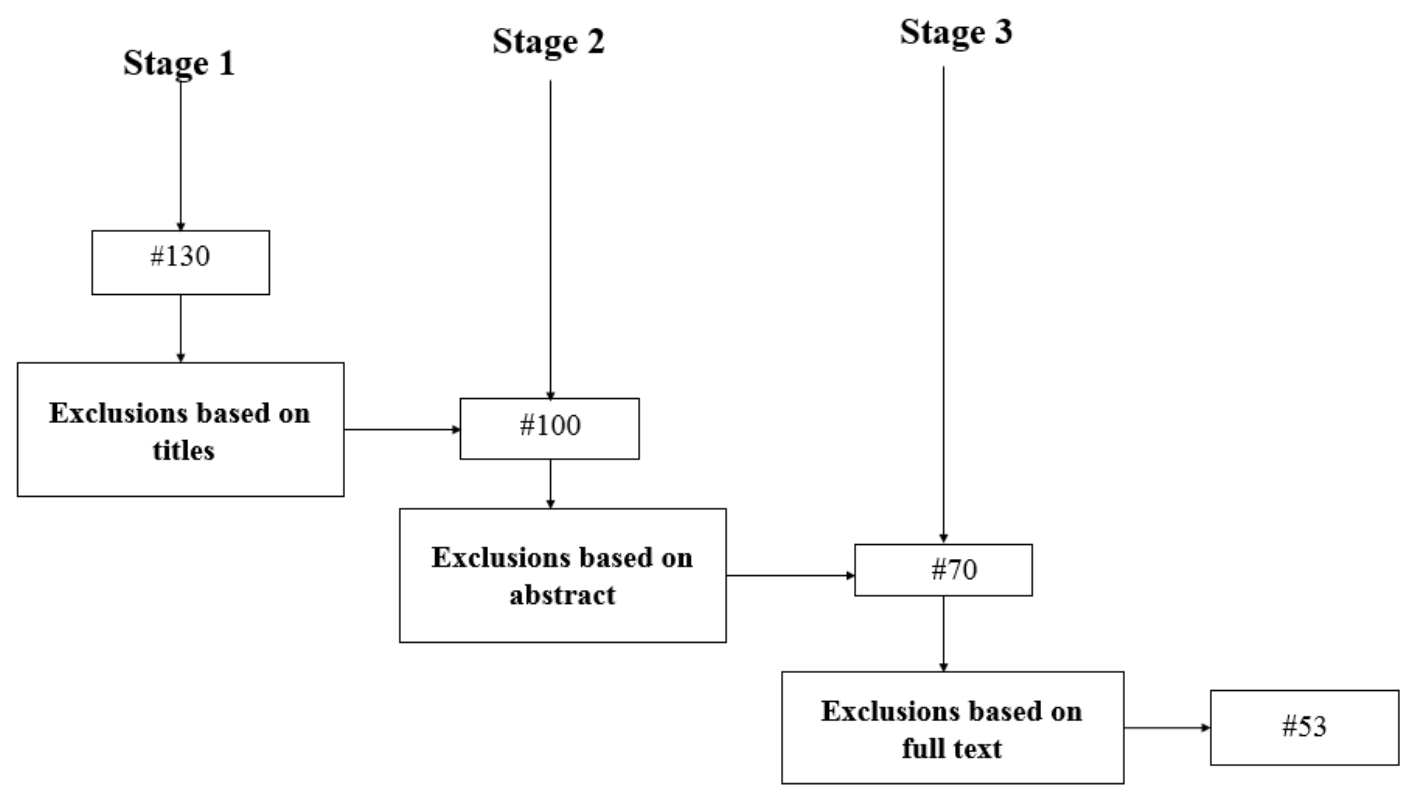

Fig.5. Study Selection Procedure

TABLE III. COMPARATIVE ANALYSIS OF VARIOUS IOT ENABLED IAQ MONITORING SYSTEMS

\begin{tabular}{|c|c|c|c|}
\hline Year & Pollutants Addressed & Type of Sensors Used & Benefits \\
\hline \multirow[t]{2}{*}{2013} & Carbon Monoxide (CO) & Not Specified & $\begin{array}{l}\text { Uses near field communication thus making the } \\
\text { proposed IAQ monitoring portable }\end{array}$ \\
\hline & TVOC's & Semiconductor Sensor & $\begin{array}{l}\text { A serious health hazard indoor air pollutant is } \\
\text { addressed with less complexity. } \\
\text { Proposed IAQ monitoring system has low cost }\end{array}$ \\
\hline 2015 & $\begin{array}{c}\text { Particulate Matter (PM 10), Carbon } \\
\text { Dioxide }\left(\mathrm{CO}_{2}\right) \text {, Nitrogen } \\
\text { Dioxide }\left(\mathrm{NO}_{2}\right), \text { Carbon Monoxide } \\
\text { (CO), Ozone }\left(\mathrm{O}_{3}\right) \text {, Oxygen, Volatile } \\
\text { Organic Compounds(VOC's), } \\
\text { Temperature and Humidity }\end{array}$ & $\begin{array}{l}\text { Semiconductor Sensors, Optical } \\
\text { Sensors, Electrochemical and } \\
\text { Thermal Sensors }\end{array}$ & $\begin{array}{l}\text { Classification of pollutants is presented along with } \\
\text { indoor air quality monitoring }\end{array}$ \\
\hline \multirow[t]{2}{*}{2016} & $\mathrm{CO}_{2}$ & Semiconductor sensor (iAQ-2000) & $\begin{array}{l}\text { Proposed IAQ monitoring application uses cognitive } \\
\text { networking technique and opportunistic routing } \\
\text { algorithm for minimum interference with existing } \\
\text { network, thus making it more efficient }\end{array}$ \\
\hline & $\begin{array}{l}\text { Carbon Dioxide }\left(\mathrm{CO}_{2}\right) \text {, Carbon } \\
\text { Monoxide }(\mathrm{CO}) \text {, and physical } \\
\text { parameters- moistness, temperature } \\
\text {, glow }\end{array}$ & $\begin{array}{l}\text { Infrared Sensors(T6615), } \\
\text { Semiconductor Sensor(MQ7), } \\
\text { SHT10 and LDR }\end{array}$ & $\begin{array}{l}\text { IAQ monitoring system is proposed with in Ambient } \\
\text { Assistant Living }\end{array}$ \\
\hline \multirow[t]{2}{*}{2017} & $\begin{array}{c}\text { Carbon Dioxide }\left(\mathrm{CO}_{2}\right) \text {, Nitrogen } \\
\text { Dioxide }\left(\mathrm{NO}_{2}\right) \text {, Carbon } \\
\text { Monoxide }(\mathrm{CO}) \text { and Sulphur } \\
\text { Dioxide }\left(\mathrm{SO}_{2}\right)\end{array}$ & Semiconductor Sensor & $\begin{array}{l}\text { Low-cost, small in size and efficient IAQM system in } \\
\text { all aspects. }\end{array}$ \\
\hline & $\begin{array}{c}\text { Nitrogen Dioxide }\left(\mathrm{NO}_{2}\right) \text {, Carbon } \\
\text { Monoxide }(\mathrm{CO}) \text { and Sulphur } \\
\text { Dioxide }\left(\mathrm{SO}_{2}\right) \text {, Ozone }\left(\mathrm{O}_{3}\right) \text { and } \\
\text { Particulate Matter }(\mathrm{PM} 2.5+\mathrm{PM} \\
10)\end{array}$ & $\begin{array}{l}\text { Laser Dust Sensor, } \\
\text { Electrochemistry Sensor }\end{array}$ & $\begin{array}{l}\text { A moving and portable IAQ monitoring system through } \\
\text { un-maned aerial vehicle (UAV) }\end{array}$ \\
\hline 2018 & $\begin{array}{l}\text { Carbon Dioxide }\left(\mathrm{CO}_{2}\right) \text {, Nitrogen } \\
\text { Dioxide }\left(\mathrm{NO}_{2}\right) \text {, Carbon } \\
\text { Monoxide(CO), Particulate Matter } \\
\text { (PM 2.5+PM 10+PM 1) and } \\
\text { meteorological parameters- } \\
\text { temperature, relative humidity }\end{array}$ & Low-Cost Sensors & $\begin{array}{l}\text { Low-Cost IAQ monitoring system, A ventilation effect } \\
\text { is formulated by considering number of occupants and } \\
\text { pollutant concentration }\end{array}$ \\
\hline 2019 & $\begin{array}{c}\text { Carbon Monoxide }(\mathrm{CO}), \\
\text { Particulate Matter, Temperature, } \\
\text { Humidity, VOC's }\end{array}$ & $\begin{array}{l}\text { Dust Sensor (GP2Y1010AU0F), } \\
\text { Semiconductor Sensors(MQ7, } \\
\text { MQ135) and DHT22 }\end{array}$ & $\begin{array}{c}\text { Low-cost, Real-time IAQ monitoring system, } \\
\text { Modelling of air quality status has beenusing Machine } \\
\text { Learning Algorithms }\end{array}$ \\
\hline
\end{tabular}




\section{B. IAQ monitoring applications for measuring other pollutants}

In one study[38] along with $\mathrm{CO} 2$, the concentration of other pollutants such as $\mathrm{NO}_{2}, \mathrm{CO}$, particulate matters (PM 10/PM 2.5/PM 1), relative humidity and temperature in indoor spaces also has been measured. The low cost environment monitoring device is built by encompasses power module, sensing module, microcontroller, Wi-Fi and Bluetooth as communication module. Calibration of sensors has been done using different machine learning algorithms. The relation between concentration of pollutants and number of students is also presented, and thus urged the need of IoT enabled ventilation system. Similar IAQM applications are proposed for measuring $\mathrm{CO} 2, \mathrm{CO}$, temperature, humidity and luminosity using WSN[19], [39] .In another study $[40] \mathrm{CO}_{2}$ and formaldehyde are measured in workspace for regulating employers health. A web based IAQM is proposed by [41]for measuring various pollutants using WSN. IAQM system presented in [8]uses Web of Things concept and uses Constrained Application Protocol (CoAP) for data collection from sensors. Pollutants presented are particulate matter- PM 2.5, PM 10, humidity, temperature, pressure, $\mathrm{CO}_{2}$, TVOC. A 'Bolt' based IoT enabled IAQM system is discussed in [42] and significant results have been achieved.

\section{IAQ Monitoring Applications using Low Cost Semiconductor Sensors}

Many researchers have worked on similar combination of pollutants detection. Semiconductor sensors are used for measuring $\mathrm{CO} 2, \mathrm{CO}, \mathrm{NO}_{2}$ and $\mathrm{SO}_{2}$ concentration in an environment in [43]. The proposed system encompasses Raspberry pi 3 based webserver for displaying and circulation of collected data to requisite users/stakeholders. Calibration of sensors is also performed for better results. In [27]semiconductor sensors are used for measuring ozone $\left(\mathrm{O}_{3}\right)$ concentrations near photocopy machine. A low cost IAQM system is presented in [44] . Semiconductor sensors are used for measuring pollutants such asCO $\mathrm{CO}_{2}, \mathrm{O}_{3}$ and $\mathrm{CO}$ and an optical sensor is used for PM 2.5. Calibration of sensors has also been done and results achieved are efficient comparing with existing systems.

Indoor Air Quality Monitoring System is also proposed in another study[45] where apart from $\mathrm{CO}_{2}, \mathrm{CO}$ three other environmental parameters are measured- Temperature, sLuminosity and Humidity. Low costwireless sensor networks(WSN's).Particulate matters such as PM 10, PM 2.5 are often present in indoors and are very dangerous for mankind [46] .The authors of this paper have proposed indoor air quality controlling and monitoring system based on Wi-Fi. The proposed system can regulate air purifier for controlling particulate matter concentration.

\section{IAQ Monitoring Applications with Pollutant Classification}

Classification of indoor air pollutants and its sources is important aspect of this study. The major cause of indoor air pollution in educational institutions and in homes respectively is presented in [23], [24].Furniture making, wall paint and occupants itself are the sources of pollution in educational institutes and in homes cleaning products, pest and insect repellents and odor neutralizers are the major causes of pollution. Principle Component Analysis is used in [24] for classification of pollutant source.

AirSense, an intelligent sensing system for homes is presented in [47]. AirSense classify pollutants according to three categories- Cook, Spray, Smoke. It also provides suggestions or action to take based on the exposure to indoor air pollution. Similarly, classification of pollutants is done based on five parameters- ambient air, foods and beverages, chemical presence, and human activity in [10]. Artificial Neural Network is used for classification in [48]. Authors have also discussed monitoring of various pollutants such as Carbon Dioxide $\left(\mathrm{CO}_{2}\right)$, Carbon Monoxide $(\mathrm{CO})$, Nitrogen Dioxide $\left(\mathrm{NO}_{2}\right)$, Ozone (O3), Particulate Matter (PM 10), Volatile Organic Compound (VOCs) and Oxygen $\left(\mathrm{O}_{2}\right)$. In [49]IAQM application is presented for pollutants $\mathrm{CO}$, VOC's, particulate matter and two physical parameters temperature and humidity. This application also classifies air quality as healthy or unhealthy using two different ML algorithms- Naïve Bayes and J48.

\section{E. Mobile and Autonomous IAQ Monitoring Applications}

There are various Indoor Air Quality Monitoring Systems proposed by different authors.But few of them are mobile and providing real-time results. One such mobile and autonomous IAQM system is presented in [18] where two chemicals factors CO, PM 2.5 and two physical factors temperature and humidity are measured and achieved effective test results. Similarly, in [50]mobile and portable IAQM system is presented for detecting particulate matter$\mathrm{PM}$ 2.5, PM 10 and gaseous pollutants such as $\mathrm{CO}, \mathrm{SO}_{2}, \mathrm{NO}_{2}$ and $\mathrm{O}_{3}$. An un-maned air vehicle (UAV) is used for mobility. Apart from that for controlling actuators of ventilators and air cleaners, fuzzy method is used. Zone based IAQM application is proposed in [51] for CO monitoring. Portable sensors are carried by users along with NFC enabled phones which are common these days.

\section{F. IAQ Monitoring System for Volatile Organic Compounds or Total Volatile Organic Compounds}

VOC's can often be found indoors. Carpets, Paints, Home Décor, Cleaning Agents, Insect Repellents etc. contains VOC's which are harmful for human health. Formaldehyde is popular among VOC's which effects human health and people are aware about it. But there are other VOCs which are present in lower concentration. Such VOC's are toxic. IAQM system for VOC's is presented in [52] which has low-cost, less complex and give reliable real-time results.

\section{G. Utilities of Indoor Air Quality Monitoring System:}

1. Health Classrooms:There is no proper definition of health classrooms but it encompasses of IoT, sensors, ventilation system, purification system, cloud, big data and notification system. Its goal is to make teachers and students comfortable in an education institution to

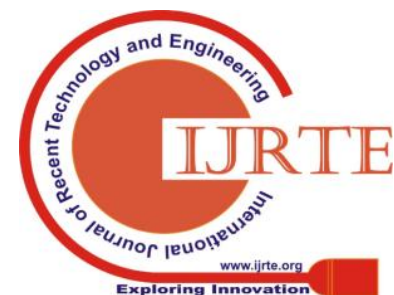




\section{Smart Indoor Air Quality Monitoring System}

promote healthy and efficient learning.

Pollutants that have been covered in this research areCO , PM 2.5, TVOC and Formaldehyde. The authors have discussed sources of these pollutants and their harmful health hazards [53].

2. AirSense:An intelligent sensing system for homes is AirSense. AirSense classify pollutants according to three categories- Cook, Spray, Smoke. It also provides suggestions or action to take based on the exposure to indoor air pollution [47].

3..Ambient Assistant Living (AAL):AAL is very vital for aging people as itleads to independent life for them. People spend around $90 \%$ of time indoors, thus monitoring of indoor air quality becomes an important aspect of AAL. Five natural parameters or pollutants are measured to know about indoor air quality. It includes air temperature, carbon monoxide, glow, moistness and carbon dioxide. This data through web can be accessed by doctors in real for diagnostics and for providing medical attention to elderly people without any delay[39].

Table 3 represents the comparison between above IAQ monitoring applications based on pollutants addressed, sensors used and also discusses benefits of different applications. Applications considered for comparison are proposed or implemented in recent years.

\section{CONCLUSIONS AND FUTURE SCOPE}

Air pollution is major health hazard for humans and other life forms. It is deadly in nature and is responsible for lung infections, stroke, respiratory problem and impacts cognition. It exists both in outdoor environment and indoor spaces. Indoor air pollution is often under-estimated but it is 2-4 more times more than outdoor spaces. Thus, monitoring and controlling of indoor air pollution is vital. This is being done using IoT. With the advent of term IoT, roughly in 2008[1], enormous amount of work in environmental monitoring is being done. IAQ monitoring systems are one part of environment monitoring applications.

The present paper has comprehensively focused on various IOT enabled IAQ monitoring applications. Thorough analysis of those applications has been done. Utilities of those applications has been discussed. The study has been done on what differentiates one IAQ monitoring from other and how results are improvised. The study stresses on how technology is important for dealing with indoor air pollution.

Thus, the survey and analysis done in the paper has been written accordingly, for studying indoor air pollution, its impact on health and the how IoT can be connected with indoor air pollution for providing technological solution for creating healthy environment and to breathe in pure air.

In future IoT enabled IAQ monitoring system, botanical air purifiers can be used. Personalized suggestions can be given to user with respect to pollutants in indoor air pollution. IoT enabled ventilation system, humidifiers, dehumidifiers can be added in existing IAQ monitoring applications. Further, research can be carried on to find links between health and other indoor venues which can lead to

sustainable indoor air environment with particular focus on energy saving and health.

\section{REFERENCES}

1. S. Madakam, R. Ramaswamy, and S. Tripathi, "Jcc_2015052516013923," J. Comput. Commun., no. May, pp. 164-173, 2015.

2. H. Arasteh, V. Hosseinnezhad, and A. Concepts, "Iot-based Smart Cities : a Survey,”2016 IEEE 16th Int. Conf. Environ. Electr. Eng., pp. 1-6, 2016.

3. D. Hanes et al., IoT Fundamentals : Networking Technologies, Protocols, and Use Cases for the Internet of Things, no. 3491. 2013.

4. "IoT applications|Top 10 uses of Internet of Things- DataFlair," DataFlair, 2018. [Online]. Available: https://data-flair.training/blogs/iot-applications/. [Accessed: 06-May-2019].

5. S. Sharma, S. Bawa, and H. Lomash, "Approaches in Cultural Computing A Survey and Inference from Social Computing with Dynamics of Mind,' Wirel. Pers. Commun., vol. 103, no. 4, pp. 2693-2713, 2018.

6. I. V Muralikrishna, V. Manickam, and E. Management, "Learn more about Environmental Pollution Introduction Societal Responsibility and Economic Viability Particulate Matter and Its Size Fraction- ation,' 2017.

7. H. N. Saha et al., "Pollution Control using Internet of Things ( IoT )," pp. 65-68, 2017.

8. J. Esquiagola, M. Manini, A. Aikawa, L. Yoshioka, and M. Zuffo, "Monitoring Indoor Air Quality by using IoT Technology," 2018 IEEE XXV Int. Conf. Electron. Electr. Eng. Comput., pp. 1-4, 2018.

9. "WHO Global Ambient Air Quality Database," World Health $\begin{array}{lll}\text { Organization, } 2019 . & \text { [Online]. }\end{array}$ https://www.who.int/airpollution/data/cities/en/. [Accessed 27-Apr-2019].

10. S. Madaan, "What are Different Types of Pollution?," Earth Eclipse. [Online]. Available: https://www.eartheclipse.com/pollution/different-types-of-pollution.html . [Accessed: 26-Apr-2019].

11. M. Mayntz, "Types of Pollution | LoveToKnow," LoveToKnow. [Online]. Available: https://greenliving.lovetoknow.com/Types_of_Pollution. [Accessed: 01-May-2019].

12. "Radiation and Pollution| Environment Pollution Centre," Environment Pollution Centre, 2017. [Online]. Available: https://www.environmentalpollutioncenters.org/radiation/. [Accessed 01-May-2019].

13. C. Xiaojun, L. Xianpeng, and X. Peng, "IOT-based air pollution monitoring and forecasting system," 2015 Int. Conf. Comput. Comput. Sci. ICCCS 2015, pp. 257-260, 2015

14. H. Xie and F. Ma, "Prediction of Indoor Air Quality Using Artificial Neural Networks," 2009 Fifth Int. Conf. Nat. Comput., vol. 2, pp. 414-418, 2009.

15. M. A. Alshamsi, Y. Anwar, M. M. Almulla, M. M. Aldahoori, N. Hamad, and M. Awad, "Monitoring Pollution : Applying IoT to Create a Smart Environment," pp. 0-3, 2017.

16. M. F. Y. A. M. Pillai, "Monitoring of volatile organic compounds in different schools : a determinant of the indoor air quality," Int. J. Environ. Sci. Technol., no. 0123456789, 2018

17. D. Devakumar et al., "Biomass fuel use and the exposure of children to particulate air pollution in southern Nepal,” Environ. Int., vol. 66, pp 79-87, 2014.

18. P. Liu et al., "A Low-Cost Intelligent Mobile Indoor Environment Monitoring System," no. Icmemtc, pp. 226-230, 2016.

19. R. Plessis, A. Kumar, G. P. Hancke, and B. J. Silva, “A wireless system for indoor air quality monitoring," IECON 2016 - 42nd Annu. Conf. IEEE Ind. Electron. Soc., pp. 5409-5414, 2016.

20. Y. Han, N. Zhu, N. Lu, J. Chen, and Y. Ding, "The Sources and Health Impacts of Indoor Air Pollution," 2010 4th Int. Conf. Bioinforma. Biomed. Eng., pp. 1-4, 2010.

21. P. Spachos and D. Hatzinakos, "Real-Time Indoor Carbon Dioxide Monitoring,” IEEE Sens. J., vol. 16, no. 2, pp. 506-514, 2016.

22. "Natural Resources Department." [Online]. Available http://csktnrd.org/ep/indoor-air-pollution. [Accessed: 06-May-2019].

23. X. Li and N. Zhu, "Indoor Air Pollution Control and Cognition Situation Investigation in University," pp. 1307-1309, 2011

24. Y. Chen and S. Shrestha, "Source Classification of Indoor Air Pollutants using Principal 
Component Analysis for Smart Home Monitoring Applications," 2018 IEEE Int. Conf. Electro/Information Technol., pp. 129-133, 2018.

25. P. V. S. S. Vamsi, A. Garg, A. Anand, and D. R. Gupta, "IOT based Air Pollution Monitoring System," vol. 8, no. 4, pp. 100-103, 2018.

26. D. Y. C. Leung, "Outdoor-indoor air pollution in urban environment challenges and opportunity INDOOR AIR POLLUTANTS," vol. 2, no. January, pp. 1-7, 2015.

27. B. H. Sudantha and P. M. Karunaratne, "IoT Enabled Proactive Indoor Air Quality Monitoring System for Sustainable Health Management," pp. 216-221, 2017.

28. M. Tuomikoski, S. Ihme, A. Huttunen, M. Korkalainen, and S. Yrjänä, "Indoor air quality sensing indicators."

29. "Air pollution and sperm quality: Breathing in toxic air may worsen semen quality," Times Now Digital, 2019. [Online]. Available: https://www.timesnownews.com/amp/health/article/air-pollution-and-sp erm-quality-breathing-in-toxic-air-may-worsen-the-semen-quality/38921 9. [Accessed: 30-Apr-2019].

30. A. Rueben, "Researchers Now Have Even More Proof That Air Pollution Can Cause Dementia," Mother Jones, 2019. [Online]. Available: https://www.motherjones.com/environment/2019/05/researchers-now-ha ve-even-more-proof-that-air-pollution-can-cause-dementia/. [Accessed: 06-May-2019].

31. X. Zhang, X. Chen, and X. Zhang, "The impact of exposure to air pollution on cognitive performance," no. August, 2018.

32. A. K. Patel and P. Biren, "Internet of Things ( IoT ): A Literature Review," vol. 4, no. 05, pp. 1001-1003, 2016.

33. D. Miorandi, S. Sicari, F. De Pellegrini, and I. Chlamtac, "Ad Hoc Networks Internet of things: Vision, applications and research challenges," Ad Hoc Networks, vol. 10, no. 7, pp. 1497-1516, 2012.

34. K. K. Khedo, R. Perseedoss, and A. Mungur, "Kavi K. Khedo 1 , Rajiv Perseedoss 2 and Avinash Mungur 3," pp. 31-45, 2010.

35. S. Singh, "Business Opportunities \& Reference Architecture for E-commerce," 2015 Int. Conf. Green Comput. Internet Things, pp. 1577-1581, 2020.

36. P. Srivatsa and A. Pandhare, "Indoor Air Quality: IoT Solution," no. March, pp. 218-220, 2016.

37. D. Lohani and D. Acharya, "and Ventilation Rate," 2016.

38. P. K. Sharma, T. De, and S. Saha, "IoT based indoor environment data modelling and prediction," 2018 10th Int. Conf. Commun. Syst. Networks, COMSNETS 2018, vol. 2018-Janua, pp. 537-539, 2018.

39. G. Marques and R. Pitarma, "An Indoor Monitoring System for Ambient Assisted Living Based on Internet of Things Architecture," 2016.

40. H. E. Fathallah, V. Lecuire, E. Rondeau, and S. Le Calvé, "An IoT-based Scheme for Real Time Indoor Personal Exposure Assessment,” pp. 2-3, 2016.

41. S. M. Saad, A. Rahman, M. Saad, A. Muhamad, Y. Kamarudin, and A Zakaria, "Indoor Air Quality Monitoring System using Wireless Sensor Network (WSN ) with Web Interface,” 2013 Int. Conf. Electr. Electron. Syst. Eng., pp. 60-64, 2013

42. P. Asthana, "IoT Enabled Real Time Bolt based Indoor Air Quality Monitoring System,” 2018 Int. Conf. Comput. Charact. Tech. Eng. Sci., pp. 36-39, 2018.

43. G. Parmar, S. Lakhani, and M. K. Chattopadhyay, "An IoT based low cost air pollution monitoring system,” 2017 Int. Conf. Recent Innov. Signal Process. Embed. Syst., pp. 524-528, 2017.

44. A. Kumar, A. Kumar, and A. Singh, "Energy Efficient and Low Cost Air Quality Sensor for Smart Buildings," 2017 3rd Int. Conf. Comput. Intell. Commun. Technol., pp. 1-4, 2017.

45. R. Pitarma, F. Caetano, and A. Monitoring, "Monitoring Indoor Air Quality to Improve Occupational Health," no. January, 2016.

46. X. Yang, L. Yang, and J. Zhang, "A WiFi-enabled Indoor Air Quality Monitoring and Control System : the Design and Control Experiments," 2017 13th IEEE Int. Conf. Control Autom., pp. 927-932, 2017.

47. B. Fang, Q. Xu, T. Park, and M. Zhang, "AirSense: An Intelligent Home-based Sensing System for Indoor Air Quality Analytics,” pp 109-119, 2016.

48. S. M. Saad et al., "Classifying Sources Influencing Indoor Air Quality (IAQ) Using Artificial Neural Network (ANN)," pp. 11665-11684, 2015.

49. D. U. Urku and H. Agrawal, "Smart Real-Time Indoor Air Quality Sensing System and Analytics," vol. 10, no. 6, pp. 1484-1495, 2019.

50. S. Zhi, "Intelligent Controlling of Indoor Air Quality based on Remote Monitoring Platform by Considering Building Environment," no. Icsai, pp. 627-631, 2017.

51. U. Engagement, "Zone Based Indoor Mobile Air Pollution Monitoring," pp. 749-752, 2013.

52. I. Peng, "Implementation of Indoor VOC Air Pollution Monitoring System with Sensor Network," 2013 Seventh Int. Conf. Complex, Intelligent Softw. Intensive Syst., pp. 639-643, 2013.
53. W. Zhang, S. Qin, and Z. Chen, "Analysis on the Construction and Application of Health Classrooms in Information Environment," pp 131-135.

\section{AUTHORS PROFILE}

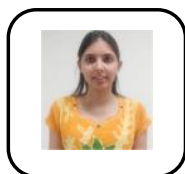

Supreet Kaur is currently pursuing M.E in Software Engineering from Thapar Institute of Engineering and Technology, Patiala. Her areas of research include IoT and cloud computing.

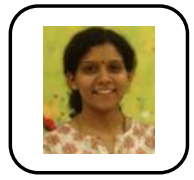

Seemu Sharma has Ph.D. degree in Computer Engineering. She iscurrently teaching in the Computer Science and Engineering Department, Thapar Institute of Engineering \& Technology, Patiala. Her area of research is cultural computing and NoSql databases. computing, human-computer interaction, IoT, cloud

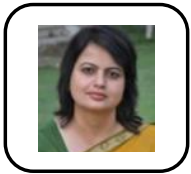

Seema Bawa an alumna of IIT Kanpur and IIT Kharagpur, has extensiveexperience in the IT industry. She is currently Professor of ComputerScience and Engineering and Professor InCharge Nava Nalanda Central Library at Thapar University, Patiala. Her areas of interest include parallel and distributed computing, grid computing, VLSI Testing, and network management. Her current research is in cloud computing, IoT and culturalcomputing 